8. Kates R., Parris T., Leiserowitz A. Great Transition Values: Present Attitudes, Future Changes. GTI Paper Series, № 9, the Tellus Institute, 2006. URL: https:// www.greattransition.org/archives/papers/Great_Transition_Values.pdf;

9. Conference of the Parties Twenty-first session Paris, 30 November to 11 December 2015. United Nations FCCC/CP/2015/L.9/Rev.1 URL:https://unfccc.int/resource/docs/2015/cop21/eng/109r01.pdf [in English].

10. Europe in transition. Paving the way to a green economy trough eco-innovation. Annual report 2012. Eco-innovation observatory. URL: https://www.eco-innovation.eu/[in English].

11. Indicators to measure decoupling of environmental pressure from economic growth. Executive summary / The OECD Environment Programme. - 3 p. URL: http://www.oecd.org/dataoecd/0/52/1933638.pdf. [in English].

12. National report - 2017 "Sustainable Development Goals: Ukraine". URL:http://www.un.org.ua/ua/publikatsii-ta-zvity/unin-ukraine-publications/4203-2017-nationalna-dopovid-tsil-staloho-rozvyatku-ukrainian-iaka-vyznachaie-bazov-pokaznykydlia-dosiahnennia-tsilei-staloho-rozvytku-tssr. [in English].

13. Pauli G. Blue Economy-10 Years, 100 Innovations, 100 Million Jobs. Grafiche Nordest , 2012. URL: http://www.management.com.ua/books/view-books.php?id=1265[in English].

14. Policies and practices for eco-innovation uptake and circular economy transition. EIO bi-annual report 2016. Ecoinnovation observatory. URL: https://www.eco-innovation.eu/[in English].

15. Raskin P. The Great Transition Today: A Report from the Future. GTI Paper Series, № 2, the Tellus Institute, 2006. URL: http://www.greattransition.org/archives/papers/The_Great_Transition_Today.pdf[in English].

16. Rifkin J. The Zero Marginal Cost Society: The Internet of Things, the Collaborative Commons, and the Eclipse of Capitalism. Palgrave Macmillan in the U.S. - a division of St. Martin's Press LLC, 175 Fifth Avenue, New York, NY 10010 , 2014. URL: https://s3.amazonaws.com/arena-attachments/678574/8d936dd16fbf9d282402b7311e488200.pdf. [in English].

17. Rifkin J. The Empathic Civilization: The Race to Global Consciousness in a World in Crisis. Penguin Group (USA) Ink., 375 Hudsom Street, New York, USA, 2009. URL: https:// http://empathiccivilization.com/read/[in English].

18. Reguly, Eric (14 December 2015). Paris climate accord marks shift toward low-carbon economy. Globe and Mail (Toronto, Canada). URL:https://www.theglobeandmail.com/news/world/optimism-in-paris-as-final-draft-of-global-climate-dealtabled/article27739122/[in English].

Дата подання публікації 18.09.2020 р.

УДК 338.43:331

Лазарєва О.В., доктор економічних наук, доцент, O. Lazarieva, Doctor of Economic Sciences, Associate Professor, Associate Professor Department of the landed resources management https://orcid.org/0000-0002-1050-7118

\title{
СУПЕРЕЧЛИВІ АСПЕКТИ ДИВЕРСИФІКАЦІЇ ЗЕМЛЕКОРИСТУВАННЯ
}

\author{
Чорноморський національний університет імені Петра Могили
}

В статті зазначено, що успішна економічна політика немислима без ефективного використання землі у сільському господарстві, активізації конкурентних переваг у сільськогосподарському землекористуванні.

Ціллю статті $€$ поглиблення теоретико-методологічних аспектів диверсифікації сільськогосподарського землекористування в сучасних умовах ринку.

В статті викладено думку, що новим стратегічним рішенням щодо ефективного розвитку $\epsilon$ впровадження процесу виробничої диверсифікації у землекористуванні, суть якого полягає у виробництві продукції, що спрямоване на зміну існуючої технології.

В умовах нових ринкових відносин політика диверсифікації справляє істотний вплив на економіку землекористування, зумовлює підвищення його конкурентоспроможності, зміцнюються позиції на вітчизняному та зарубіжному ринках.

Диверсифікація сільськогосподарського землекористування поділяється на первинну (диверсифікація першого порядку) і вторинну (другого порядку). Паювання земель за результатами роздержавлення і приватизації являють собою первинну диверсифікацію. 
На селі необхідним є перехід до індикативного планування, що сприятиме досягненню соціальноекономічних індикаторів розвитку виробництва на селі. Назріла необхідність впровадження змін у законодавчі акти, які б забезпечували гарантію непорушності сформованих землекористувань.

Зазначено, що політика диверсифікації справляє істотний вплив на економіку землекористування, зумовлює підвищення його конкурентоспроможності, зміцнюються позиції на вітчизняному та зарубіжному ринках.

Диверсифікації сільськогосподарського землекористування має бути орієнтована на створення земельних та земельно-майнових комплексів, об'єднаних у компактний масив з визначеним цільовим його використанням, площа якого має визначатись організаційно-економічними можливостями суб'єкта господарювання на землі.

Необхідним є проведення консолідацію земельних ділянок, яка б сприяла забезпеченню сталого землекористування.

Ключові слова: диверсифікація, землекористування, конкурентоспроможність, індикативне планування, земельні паї, сільськогосподарське виробництво.

\title{
CONTROVERSIAL ASPECTS OF LAND USE DIVERSIFICATION
}

\author{
Petro Mohyla Black Sea National University
}

It is marked in the article, that successful economic politics is unthinkable without the effective use of la nd in agriculture, activations of competitive edges in agricultural land-tenure.

The purpose of the article is deepening of theoretical and methodological aspects of diversification of agricultural land-tenure in the modern terms of market.

An idea is expounded in the article, that a new strategic decision in relation to effective development is $\mathrm{i}$ ntroduction of process of productive diversification in landtenure, essence of that consists in the production of goods, that is sent to the change of existent technology.

In is conditions of new market relations politics of diversification renders substantial influence on the economy of land-tenure, predetermines the increase of his competitiveness, positions become stronger on home and foreign markets.

Diversification of agricultural land-tenure is divided into primary (diversification of firstorder) and secondary (second order).

Dividing into parts of land on results privatizing show a soba primary diversification.

On a village a necessity is passing to the indicative planning that will assist the achievement of socioeconomic indicators of development of production on a village.

Coming to a head necessity of introduction of changes in legislative acts, that would provide the guarant ee of inviolability of the formed land-tenures.

It is marred that politics of diversification renders substantial influence on the economy of land-tenure, predetermines the increase of his competitiveness, positions become stronger on home and foreign markets.

Must be oriented diversification of agricultural land-tenure to creation of the landed and land-property complexes, incorporated in a compact array with having a special purpose his certain use, the area of that must be determined by organizationally-economic possibilities of subject of manage on the land.

It is marked in the article, that with the aim of rational organization of territory of cropland it is necessary to conduct consolidation of lot lands, that would assist providing of permanent landtenure, id est to create the integral, indissoluble field of totality of plugged in the process of diversification of the landed shares. It will allow to avoid spatial inconveniences.

Key words: diversification, land-tenure, competitiveness, indicative planning, landed shares, agricultural production.

Постановка проблеми у загальному вигляді i iï зв'язок 3 важливими науковими та практичними завданнями. Успішна економічна політика немислима без ефективного використання землі у сільському господарстві, активізації конкурентних переваг у сільськогосподарському землекористуванні. Вона $\epsilon$ передумовою продовольчої безпеки нації. 3 нею пов'язаний сільський спосіб життя, традиційні цінності, носіями яких є селянство.

У цьому зв’язку необхідним $є$ вивчення пріоритетів розвитку процесу диверсифікації в землекористуванні, що формують тенденції розвитку національної 
економіки, iii конкурентоспроможності на внутрішньому i зовнішньому ринках, опанованого на основі знань інноваційного характеру власної моделі модернізації.

Аналіз останніх досліджень, у яких започатковано вирішення проблеми. Проблеми диверсифікації діяльності були і залишаються предметом досліджень багатьох вчених-економістів. Зокрема, Мухаммадбек Махсудов [1] обгрунтував необхідність ефективного використання земель всіх категорій на основі диверсифікації виробництв, створенні нових робочих місць та приватизації прав землекористування для створення комфортного життя.

Багорка М.О. [2] диверсифікацію вбачає в орієнтації на інноваційний шлях розвитку, який вимагає від товаровиробників наявності асортименту, що складається 3 кількох підходів продукції, що знаходяться на різних етапах життєвого циклу та взаємно доповнюють один одного.

Шеленко Д.І. [3] диверсифікацію розуміє як кінцевий результат впровадження нової або вдосконаленої продукції (послуги), організації виробництва, системи його управління з метою одержання різних видів ефекту.

Ткачук B.I. [4] розглядає проблему диверсифікації сільської економіки країн Європейського Союзу в контексті реалізації політики регіонального розвитку.

Скоробогатов М.M. [5, с. 19] диверсифікацію виробництва у сільському господарстві вбачає у вході підприємства до нових для нього сфер бізнесу.

Комліченко О.О. [6] диверсифікацію вбачає у таких випадках, коли підприємство на ринку має монопольну позицію, коли підвищуються запаси капіталу і виникає потреба в його використанні.

Зінчук Т.О. [7] у своїх наукових працях доводить, що диверсифікацію виробництва необхідно сфокусувати на використанні «ноу-хау» та інноваційних технологій для підвищення конкурентоспроможності продукції у сільських територіях, а також поліпшення якості життя у сільській місцевості.

Германюк Н.В. [8] обгрунтовує, що реалізація стратегії диверсифікації уможливлює доповнити вже існуючий бізнес новими видами діяльності, оптимізувати використання наявного виробничого потенціалу, сприятиме працевлаштуванню молоді на селі.

Однак проведений аналіз літературних досліджень вчених свідчить, що питанню вивчення аспектів диверсифікації саме землекористування приділено недостатньо уваги.

Зазначений факт потребує більш змістовного аналізу та розробки відповідних науково обгрунтованих пропозицій.

Цілі статті. 3 урахуванням вищевикладеного метою статті $є$ поглиблення теоретико-методологічних аспектів диверсифікації сільськогосподарського землекористування в сучасних умовах ринку.

Виклад основного матеріалу дослідження 3 повним обгрунтуванням отриманих наукових результатів. У сільському господарстві земля виступає не тільки матеріальною умовою галузі національного господарства, але й активним фактором виробництва, виконуючи дві функції - предмет праці, на який людина впливає у процесі виробництва i як знаряддя виробництва, за допомогою якого вирощуються сільськогосподарські культури. Враховуючи цю обставину земля в аграрному секторі економіки виступає головним засобом виробництва.

Проте в українській економіці сьогодні необхідних кроків щодо більш глибокого перегляду соціально-економічних відносин взагалі і в сільському господарстві, зокрема, не робилося, відповідні механізми не відпрацьовувалися. Внаслідок цього відбулося те, що Україна виявилась не підготовлена в достатній мірі до стратегічного управління соціально-економічними процесами в аграрному секторі економіки. 
Відповідно перед вищими органами влади постало завдання необхідності формування та реалізації принципово нових стратегічних рішень щодо ефективного розвитку країни.

Одним 3 таких стратегічних орієнтирів є впровадження процесу виробничої диверсифікації у землекористуванні, суть якого полягає у виробництві продукції, що спрямоване на зміну існуючої технології. Мова йде про перехід при виробництві на селі до індикативного планування, яке допомагає визначити напрямки розвитку господарського комплексу, інформує зацікавлені сторони про потенційний попит, стан справ у суміжних галузях, наявність робочої сили, інші питання. При цьому гарантуються рівності всіх форм власності на землю, заохочується здорова конкуренція, захист споживачів продукції, здійснюється соціальний захист населення, формується конкурентоспроможний ринок та інші інститути ринкової інфраструктури, спрямовані на вирішення комплексу проблем забезпечення сталого еколого-економічного розвитку держави і підвищення життя якості населення.

Принципово тут виділити «горизонтально інтегровану диверсифікацію, за якої сільськогосподарська продукція однієї галузі може бути використана на виробниче споживання в інших сільськогосподарських галузях та горизонтально неінтегровану диверсифікацію, за якої сільськогосподарські галузі по відношенню одна до одної діють автономно» [9].

Саме тому політика диверсифікації справляє істотний вплив на економіку землекористування, зумовлює підвищення його конкурентоспроможності, зміцнюються позиції на вітчизняному та зарубіжному ринках.

Відзначимо, що диверсифікація сільськогосподарського землекористування поділяється на первинну (диверсифікація першого порядку) i вторинну (другого порядку). Паювання земель за результатами роздержавлення і приватизації являють собою первинну диверсифікацію.

Крім того, управлінські впливи на ефективність процесів диверсифікації землекористувань визначаються термінами договорів оренди земельних часток, які виступають ареною гострої боротьби між орендарями та орендодавцями. Нині економічна політика орендарів грунтується на передачі в оренду земельних паїв переважно на 6-10 років, що $\epsilon$ головною причиною не тільки нестабільності землекористування, але й причиною його деструктивних процесів - спадання природної родючості грунту, забрудненості земель мінеральними добривами та хімічними засобами захисту рослин, породжує нересурсозберігаючий характер використання землі, а споживацький, що створює небезпечний вплив на навколишнє середовище.

Досліджуючи вплив способу використання землі на конкурентні позиції сільськогосподарських товаровиробників виявилось, що нині немає ніяких доказів, які б охоплювали весь аспект негативних процесів у рамках маркетингового року. Ми схиляємося до думки, що тут має місце, так звана, часова асиметрія, яка трактує часовий інтервал між настанням подій і причиною їх виникнення. Тобто тут мова йде про те, що події (наслідки), власне, починають себе проявляти дещо пізніше - після закінчення короткотермінової оренди земельних паїв. Відтак, часта зміна орендарів породжує в накопичувальному порядку цілу сукупність деструктивних процесів у землекористування. Виходячи 3 цього, автор відстоює апріорний характер довготермінової оренди, яка служить стабілізатором всіх еколого-економічних процесів землекористування.

Проте такі випадки можна віднести до ідеальної моделі формування землекористування ринкового типу. Однак у дійсності така умова не досягається через прояви намагання орендодавців розірвати договірні угоди 3 орендарями 3 метою організації одноосібного господарства. 3 одного боку перевагами такої форми 
господарювання, $є$ те, що власник паю власноручно працює на своїй землі, отримуючи економічний зиск на один порядок вищий, ніж від розміру орендної плати. Однак, при цьому власники паїв вступають у корупційні відносини з іншим будь-яким фермером чи іншим суб’єктом господарювання на землі, передавши свої земельні ділянки без оформлення договору про передачу землі в оренду. При цьому орендодавець може отримати навіть дещо більшу орендну плату ніж у попередньому випадку, а орендар уникне від сплати податку за землю, через що відповідні бюджети не отримають надходжень. В окремих випадках такі оборудки в області складають до 70\%, що відкрито призводить до тіньової економіки в агросфері.

Більш того, вихід із земельним паєм з метою ведення одноосібного господарства руйнує цілісність, наприклад, фермерського господарства, а при масовому виході це може призвести до повного обезземелення суб'єкта господарювання на землі, якому вдалося придбати технічних засобів на десятки мільйонів гривень, розвинути інфраструктуру із зберігання та переробки продукції тощо.

Ці обставини вимагають термінового впровадження відповідних змін у чинне законодавство, яке б забезпечувало гарантії непорушності вже сформованих землекористувань, незалежно від форм господарювання - це з одного боку, а з іншого необхідно, щоб орендодавці повірили в орендаря, у контексті того, що останній поступається місцем приватних інтересів у користь розвитку сільських територій, соціального захисту власників паїв та ін.

Тут мова йде про те, що наймогутнішим засобом забезпечення сталого розвитку землекористувань $є$ спільна діяльність багатьох людей, здійснення відповідного контролю за своєчасним наданням певної допомоги селянам та ін. Практична реалізація такої філософії господарювання на орендованих земельних паях принесе тривалий стратегічний успіх і процвітання фермерського господарства та значне задоволення матеріальних благ орендодавцям.

Показовим у контексті результативності диверсифікації сільськогосподарського землекористування коли управлінська діяльність орієнтована на створення земельних та земельно-майнових комплексів.

У сьогоднішньому розумінні земельний комплекс являє собою «конструкцію» земельних паїв, об'єднаних у компактний масив 3 визначеним цільовим його використанням. Однак успішною диверсифікація може бути тоді, коли сформовані масиви, спираючись на землевпорядний процес, мають визначені і погоджені межі із суміжними суб'єктами господарювання на землі. Іншими словами, доцільним є створення інвестиційних комплекси під майбутніх суб' єктів господарювання на землі. 3 цією метою, для активного залучення первинних інвестиційних ресурсів створюється інвестиційна компанія, де головним іiі засновником виступає адміністрація, володіючи контрольним пакетом акцій. Співзасновниками можуть бути інвестиційні, фінансові, землевпорядні, консалтингові та інші організації.

Але така практика формування диверсифікованих земельних комплексів, на нашу думку має методологічні зауваження стосовно недоцільності виконання комплексу землевпорядних дій, пов'язаних із процедурою виготовлення землевпорядної документації на абстрактний неіснуючий об'єкт управління, що «нав'язується» майбутньому суб' єкту господарювання на землі. Така схема диверсифікації може бути придатною, наприклад, при встановленні меж для промислових об'єктів (заводи, фабрики, цеха тощо), площа яких регламентується будівельними нормами і правилами.

Площа ж сільськогосподарського землекористування визначається технікотехнологічними, фінансовими можливостями суб'єкта господарювання, наявністю трудових ресурсів, рівнем розвитку маркетингу тощо. Так, для одного суб'єкта 
господарювання оптимальною площею землекористування є 5 тис. га, для іншого - одна тисяча, а комусь забагато 100 га.

Але поряд 3 цим в Україні існує безліч особливо великих за розмірами землекористувань, площа яких сягає до 300 і більше тисяч гектарів, створених на основі оренди земельних часток(паїв). До них відносяться «Ренесанс Груп (Росія)», «Українські аграрні інвестиції», «Стівен Дженнінгс», «ЛендВест», «Дакор», площа яких складає 300 і більше тисяч гектарів одних земель. Багато інших таких, як «Нафком-Агро», ТМ «Наша ряба», «Агротон», Райз-Агро», «Євроінвестбуд» мають в оренді від 200 і більше гектарів. Є багато «дрібніших» агрохолдингів - «Укррос» - 105 тис. га, «Лотуре» - 101 тис. га, «Стіомі Холдинг» - 98 тис. га, «Кернел» - 85 тис. га і багато інших латифундій , хоча дещо меншими за розмірами [10]. Сьогодні суперечливий характер функціонування i розвитку соціальної сфери на селі не подолано, а технології використання орних земель носять екологічно руйнівний характер, урожайність нижча від показників урожайності фермерських господарств в рамках одних і тих природно-економічних умов. Якщо говорити про розвиток землекористування латифундій, то вони не вирішують ні економічних, ні соціальних проблем людини на селі.

Тому вибір і формування організаційної структури при всій іiї важливості i значимості все ж є похідною від такого феномену як управління і менеджменту, забезпечення відповідності повноважень, функцій та міри відповідальності кожного конкретного керівника 3 його реальними можливостями, здібностями та іншими якостями.

Відтак майже неможливо передбачити процеси диверсифікації на території сільської ради щодо кількості одиниць та площі земельних комплексів: чи їх буде один, два, а може і значно більше. Крім того, неможливо передбачити наміри того чи іншого суб'єкта господарювання на землі. Стосовно цього, на наше переконання такі методологічні підходи до створення умов диверсифікованого ефективного землекористування є хибними. Організаційні стратегії, спрямовані на диверсифікацію землекористування повинні розглядатись через призму цілей, інтересів і мотивів різних учасників земельних відносин. При цьому уявляється цілком очевидним, що з метою раціональної організації території орних земель, тобто земельних часток (паїв) з участю земельної комісії кожної із сільських рад щонайбільше необхідно провести консолідацію земельних ділянок, тобто створити цілісне, нерозривне поле сукупності включених у процес диверсифікації земельних паїв. Це дозволить уникнути просторових незручностей: черезсмужжя, вкраплення, геометричних характеристик (форма, цілісність, компактність, віддаль та ін.).

Змістовний аспект вищеприведеного полягає в тому, що по мірі затребуваності земельної площі для організації ведення сільськогосподарського виробництва вона буде виділятись єдиним компактним масивом, що відповідатиме організаційній стратегії ринкового землекористування.

Але у землевпорядній та спеціальній літературі методологічні положення диверсифікації землекористування на основі консолідації земельних ділянок не тільки не розроблені, але й не зачеплені. Для переважної більшості суб'єктів господарювання на землі, через розмитість поняття суб'єктно-об'єктних відносин, через відсутність взаємної адаптації суб'єкта і об'єкта управління процесом диверсифікації землекористування уявляється як можливість збагачення у короткостроковому періоді, порушуючи морально-етичні норми існування високої корпоративної культури, що призводить до переростання цих відносин у конфлікти.

Отже, суттєві зрушення у контексті життєвих цінностей та ідеалів визначають становлення і розвиток земельних відносин ринкового типу. Надзвичайно важлива роль щодо зміни цілей і характеру земельних відносин у ринкових умовах належать 
диверсифікації землекористування. Але відсутність методологічних положень, практичних рекомендацій із згадуваної проблеми істотно ускладнює процес управління логікою і структурою побудови диверсифікованих сільськогосподарських підприємств. Основним завданням методології при цьому є не стільки дати готовий рецепт на всі випадки практики управління земельними ресурсами, скільки визначити загальні підходи та принципи успішної диверсифікації сільськогосподарських підприємств.

Висновки. Поглиблення ринкових трансформацій у сільськогосподарському землекористуванні не можливе без якісно нової концепції збереження і відтворення земельно-ресурсного потенціалу, відтворення енергетичного потенціалу сільськогосподарських земельних угідь, стратегії досягнення балансу інтересів землевлевласників і користувачів землі та пов'язаних з цим антропогенно змінених агроландшафтів. Важливим напрямком якісно нового підходу $є$ методологія, що спирається на диверсифікацію землекористування, яка $є$ головною умовою формування земельних відносин ринкового типу, досягнення головної мети - підвищення соціального добробуту населення, рівня та якості його життя.

Отже, теоретико-методичні засади диверсифікації виробництва на землі, що дозволяють сформувати конкурентоспроможне землекористування, мають бути адаптовані до матеріально-фінансових можливостей суб'єкта господарювання, можливостей залучення інноваційного потенціалу, здатності до процесу стратегічного планування землекористування, розвитку маркетингу та політики розвитку регіону.

На селі необхідним є перехід до індикативного планування, що сприятиме досягненню соціально-економічних індикаторів розвитку виробництва на селі. Назріла необхідність впровадження змін у законодавчі акти, які б забезпечували гарантію непорушності сформованих землекористувань.

Результативність диверсифікації сільськогосподарського землекористування має бути орієнтована на створення земельних та земельно-майнових комплексів, об'єднаних у компактний масив 3 визначеним цільовим його використанням. Відповідно площа сільськогосподарського землекористування має визначатись організаційноекономічними можливостями суб'єкта господарювання на землі.

3 метою раціоналізації території орних земель, тобто земельних часток (паїв) 3 участю земельної комісії кожної із сільських рад щонайбільше необхідно провести консолідацію земельних ділянок, яка б сприяла забезпеченню сталого землекористування.

Подальші дослідження мають бути орієнтовані на вивчення безпосередньо процесу трансформації землекористувань в земельно-майнові комплекси.

\section{Список бібліографічного опису}

1.Мухаммадбек Махсудов Диверсификация землепользования является фактором развития. LAP LAMBERT Academic Publishing, $104 \mathrm{c}$.

2.БагоркаМ. О., Білоткач І.А. Диверсифікація як фактор підвищення ефективності діяльності підприємств в сучасних умовах. Інвестиції:практика та досвід. 2009. №10. С. 17 - 21.

3.Шеленко Д.І., Матковський П.С., Баланюк С.І. Основні напрями забезпечення системності диверсифікації діяльності аграрних підприємств. Інноваційна економіка. 2015. № 2. С. 82-85.

4.Ткачук В.І. Диверсифікація сільської економіки як напрям регіональної політики СС. Регіональна економіка. 2011. № 3. C. 149-158. URL: http://nbuv.gov.ua/UJRN/regek_2011_3_18 (дата звернення 25.09.2020)

5.Скоробогатов М.M., Куцерубова О.І. Диверсифікація як один із шляхів підвищення ефективності діяльності підприємств у сучасних умовах. Економічний вісник Донбасу. 2011. № 3 (25). С. 18-21. (дата звернення 26.09.2020)

6.Комліченко О. О. Диверсифікація діяльності сільськогосподарських підприємств як основа підвищення конкурентоспроможності. URL: http://www.rusnauka.com/31_PRNT_2010/Economics/73612.doc.htm(дата звернення 26.09.2020).

7.Зінчук Т. О., Ткачук В.І. Теоретично-методологічні засади диверсифікації сільської економіки в контексті європейського досвіду. Економіка АПК. 2011. № 1. С. 27-34.

8.Германюк Н. В. Теоретико-методичні аспекти диверсифікації в сільському господарстві. Економіка АПК. 2010. № 8. С. 25-29.

9.Андрійчук В.Г. Економіка аграрних підприємств: підручник. 2-е вид., доповн. і перероблене. К.: КНЕУ, 2002.624 с. 
10. Зущик Ю. Кому достанеться украинская земля. Новая газета, 22 июля, 2010 года. URL: https://novayagazeta.ru/issues/3001 (дата звернення 27.09.2020)

\section{References}

1.Mhammadbak Mahsudov Diversifikacia zemlepolzovania yavlaetsya faktorom razvitia. LAP LAMBERT Academic Publishing, $104 \mathrm{c}$.

2.Bagorka M., Bilotkach I. Diversifikacia yak factor pidvichennya diyelnosty pidpriemstv v suchasnih umovah. Investicii: prattika ta dosvid, 2009, vol. 10, pp. 17-21 [in Ukrainian].

3.Shelenko D., Matkovsty P., Balanuk S. Osnovni napryami zabezpechennya sistemhoi diversifikacii dialnosty agrarnih pidpriemstv. Innovaciyna economica, 2015, vol. 2, pp. 82-85. [in Ukrainian].

4.Tkachuk V.I. Diversifikacia silskoy ekonomiky yak napryam regionalnoy politiky ES. Regionalna economika, 2011, vol. 3, pp. 149-158. Available at: http://nbuv.gov.ua/UJRN/regek_2011_3_18 (accessed 25.09.2020).

5.Skorobagatov M., Kucerubova O. Diversifikacia yak odin iz shlyahiv pidvichennya efektivnosty diyalnosty pidpriemstv u suchasnih umovah. Ekonomichny visnik Donbasu, 2011, vol. 3 (25). pp. 18-21. [in Ukrainian].

6.Komlichenko O.O. Diversifikacia diyalnosty silskogospodarskih pidpriemstv yak osnova pidvicennya konkurentospromognosty. Available at: http://www.rusnauka.com/31_PRNT_2010/Economics/73612.doc.htm (accessed 26.09.2020).

7.Zinchuk T., Tkachuk V. Teoretichno-metodologichny zasady diversifikacii silskoy ekonomiky v koneksty evropeyskogo dosvidu. Ekonomika APK, 2011, vol. 1. pp. 27-34. [in Ukrainian].

8.Germanuk N.V. Teoretiko-metidichny aspekty diversifikacii v silskomu gospodarstvy. . Ekonomika APK, 2010, vol. 8. Pp. 25-29. [in Ukrainian].

9.Andriychuk V.G. Ekonomika agrarnih pidpriemstv. Pidruchnik. 2-e vid. dopovn. I pererobl. K.: KNEU, 2002. 624 p. [in Ukrainian].

10. Zychik U. Komu dostanetsya ukraonskaya zemlya. 22 iulya, 2010 g. Available at: https://novayagazeta.ru/issues/3001 (accessed 27.09.2020).

Дата подання публікації 28.09.2020 р. 